British Journal of Education

Vol.8, Issue 2, pp.1-12, Feburary 2020

Published by ECRTD- UK

Print ISSN: ISSN 2054-6351

Online ISSN: ISSN 2054-636X

\title{
FACTORS THAT IMPACT TEACHERS' LEARNING: MERGING TECHNOLOGY WITH EDUCATION IN PROFESSIONAL DEVELOPMENT
}

\author{
Dr. Maisoun Alzankawi \\ Language Centre, The Public Authority for Applied Education and Training, Kuwait
}

\begin{abstract}
In recent years, technology's value is realized through how it has become part of our daily lives. As technology continues to evolve, so do people's need to be updated with it. Teachers are one of the many professionals who can productively benefit from technology. The adoption of digital technologies in the education sector has enabled teachers to access content and assisted them in providing instruction. Moreover, the Internet helps teachers to share and compare ideas with colleagues. Since the use of technology has become commonplace, it is advisable to train teachers on how they can effectively use digital devices in the classroom. This paper examines how technology can help teachers in the classroom and explores professional development as an essential element in assisting teachers to adapt to the constant technological advances. Furthermore, the study explores how technology is being incorporated into the classroom. The study also discusses the controversy behind its use. The paper draws from past literature on the use of technology in teachers' professional development.
\end{abstract}

KEYWORDS: technology, education, professional development, influence

\section{INTRODUCTION}

From simple tasks of writing and sending reports and emails to many other functions, technology has become an important tool and has contributed in many ways to many societies. Students have been using technology in and outside the classrooms, and they regularly interact with it. Thus, students need 21 st-century skills to be successful in college and their future careers. Additionally, technology offers resources for teachers to improve ESL instruction, such as authentic writing activities, grammar instruction, lesson plans, and other central topics. Computers, tablets, and ereaders can all be instrumental in learning English, offering interactive and motivating activities for students of all ages. Audiobooks can be used to supplement reading instruction and improve comprehension.

This research is a descriptive study that aims to explore what technology can do to help teachers with their professional development through a program that incorporates technology such as online training, and the factors that affect the selected teachers' learning. The study discusses the impact of using technological tools of education and class teaching. Recommendations are also provided to improve the use of educational technology in educational settings. 
British Journal of Education

Vol.8, Issue 2, pp.1-12, Feburary 2020

Published by ECRTD- $U K$

Print ISSN: ISSN 2054-6351

Online ISSN: ISSN 2054-636X

\section{LITERATURE REVIEW}

There is a need for teachers to equip themselves with the demands and trends in education continually. Because technology is a valuable resource, it is important that teachers keep up as technology changes. Evidently, technology enables them to address the rapidly evolving student needs. However, there are limitations that emanate from teacher time and budget constraints. A study by Linda (2018) examined the various ways of maximizing professional learning in training teachers on how to use technology. The researcher concluded that the trainer should use different formats while providing instructions to teacher trainees. It is essential to combine online instruction with face-to-face training. This way, the needs of self-directed learners and others who need a high-touch learning environment can be accommodated. Another approach that could be used to maximize learning is by keeping the learning sessions short. Individual professional development sessions organized by the teachers should last for about half an hour, and be conducted when the teacher is out of school. Recording of sessions is vital because they can be availed to teachers for playback, and this optimizes their time.

A research study conducted by Betrus \& Molenda (2002) traces the evolution of technology and its use in teacher education programs. The article states that education is not a new concept in teacher education programs; it has existed for many years. The use of technological media in teaching has been incorporated in the programs since the 1900s. The earliest visual instruction courses were offered in 1918 at the University of Minnesota. From the 1940s to 1960s, there was a gradual evolution of the content incorporated in the programs. The use of technology in teacher education became common and spread to other parts of the world. With technological advancements, technology has been incorporated into teacher education. In modern times, technology has become necessary in teacher training because teachers also use it to instruct students.

In another study by Galaczi, Nye, Poulter, \& Allen (2018), the researchers focus on teacher professional development. The scholars acknowledge that one of the essential elements is ensuring teachers possess the right skills because this helps in raising English standards. As highlighted in the research, learning technologies have greatly influenced the teaching of the English language. Nonetheless, the study finds that both the in-service and pre-service English teachers are illequipped because they do not have the adequate skills to incorporate technology in classroom instruction. The lack of training and knowledge of integrating technologies in ELT classes are primary concerns. The study further reveals that the most critical skills that teachers should possess are the ability to incorporate knowledge of new technologies and ICT skills in the classroom. Thus, digital technology is a significant component of contemporary language education.

Another research by Richards and Farrell (2005) evaluated the aspect of professional development among language teachers and the appropriate strategies that can be used to facilitate learning. The research relates to the study conducted by Galaczi et al. In the study, Richard and Farrell state that teacher education focuses on the achievement of two broad goals, and they include training and 
British Journal of Education

Vol.8, Issue 2, pp.1-12, Feburary 2020

Published by ECRTD- UK

Print ISSN: ISSN 2054-6351

Online ISSN: ISSN 2054-636X

development. The training aims to achieve the immediate and short-term goals set by the teacher. It entails an understanding of the basic concepts related to the profession and their application in teaching. Further, teacher training requires the aspect of trying new strategies.

On the other hand, development involves the growth that is not necessarily focused on a specific task. It seeks to enhance long-term goals and facilitate teachers to gain an understanding of themselves. Some of the strategies used for teacher development include reflective analysis, talking with peers about core issues, and examination of values, beliefs, and principles. The researchers also noted that teachers have intense pressure to improve their knowledge in the use of technology.

A study by Liu, Tsai, \& Huang (2015) has explored the professional development of pre-service teachers and mentor teachers with regard to technology integration. The researchers examined how teachers can integrate technology into instruction. Based on the research, integration can be done through the use of content and pedagogical knowledge in the evaluation of professional development. The researcher further observes that mentor teachers can adjust their methods of instruction when they get support from pre-service teachers. The pre-service teachers are involved in the application of technological pedagogical knowledge (TPK) and technological content knowledge (TCK) for professional development.

Moreover, the researchers found out that integration of technology in the classroom enhances learning efficacy, increases student motivation, and promotes creativity. Although most teachers have access to technology, they fail to incorporate it into their teaching. Unsuccessful experiences in the use and adoption of technology inhibit the motivation of teachers. Thus, there is a need to establish successful classroom experiences that enhance technology integration.

Philips (2008) examines professional development as an essential component that enhances teacher quality. The author states continuity of learning is one of the most important determinants of teacher success. The government should prioritize the professionalism and quality of teachers through continuous training. The study acknowledges that work practices have rapidly changed, and this means that teachers should be computer literate. Professional development is a critical component of educational reform. Changes take place when there is systematic and relevant professional development. Information technology is one of the typical changes experienced in the field of education. Although many teachers were not using computers in the past, numerous changes have occurred recently. There are different ways in which computers are used, and these include lesson delivery, lesson preparation, communication, and research. The paradigm shift requires the use of a systematic approach to teacher professional development. The systematic approach should take into account some criteria. One of the criteria is the integration of development with a change process. Another criterion is planning development to suit both the individual and school needs. 
British Journal of Education

Vol.8, Issue 2, pp.1-12, Feburary 2020

Published by ECRTD- UK

Print ISSN: ISSN 2054-6351

Online ISSN: ISSN 2054-636X

In an article written by Chong (2018), the author has explored ten innovations and trends in the teaching of the English language. The author holds that technological innovations are essential aspects of English language teaching and education. One of the trends is blended learning, which has emerged from the combination of traditional teaching methods with digital media. Some courses offered by institutions of higher learning combine online lessons with face-to-face teaching. Another trend is mobile learning; this involves access to online resources using mobile apps. Some of the applications are used to make vocabulary learning easy and comprise of activerecall learning to enhance the understanding of new words. The other trend is gamification, which uses friendly matches and training sessions to enhance vocabulary learning. Embodied learning is another trend, and it is based on the assumption that learning does not only entail remembering but also collaborating, use of body and mind, as well as exploring.

As demonstrated by Chong (2018), another trend in English language teaching is inquiry-based learning. Teachers encourage teenagers to practice communication and soft skills, which are essential in the $21^{\text {st }}$-century global community. Through this trend, learners and teachers discover the use of grammars for self-expression. The acceptance of the English language as a lingua franca (ELF) is another trend. When it was first discussed, the trend turned out to be controversial because of its ability to fit into language teaching and course materials. The other common trend is translanguaging and multi-literacies, which entails encouraging learners to use their native language. The focus on the linguistic diversity of teachers has formed the basis for modern instructional strategies in English classrooms. Overall, an understanding of these trends is vital for teachers because it can help them to understand the need for integrating technology in teaching.

A study conducted by Darling-Hammond et al. (2017) highlighted the effective approaches to professional development among teachers. Based on the article, effective professional development is focused on content. This means that the teaching strategies used have to emphasize on the specific content of the curriculum. Moreover, it has to support collaboration in the sense that teachers should be given an opportunity to collaborate and also share ideas. Collaboration enables teachers to create communities that bring positive change to the instruction and culture of their grade level. The author further notes that professional learning can be enhanced through the provision of technology-facilitated opportunities for teachers.

Moreover, technology is essential in teacher training because it facilitates standards-based instruction. The use of technology to support professional development enhances cyber collaboration, which improves the skill level of teachers and promotes student achievement. Thus, technology is an essential component of teacher training because it benefits trickle down to students. Casteel and Ballantyne (2010) evaluated the application of professional development by studying how teaching can be improved for English learners. As highlighted in the text, numerous schools in the United States are experiencing a shortage of teachers to coach English language learners (ELL). Therefore, there is a need for professional development (PD) to staff schools that admit ELL students. PD refers to the practices and processes that are essential in the improvement of job-related skills, knowledge, and attitudes of teachers. The knowledge and skills gained 
British Journal of Education

Vol.8, Issue 2, pp.1-12, Feburary 2020

Published by ECRTD- UK

Print ISSN: ISSN 2054-6351

Online ISSN: ISSN 2054-636X

through PD should guarantee the well-being and improvement of every student. One of the core principles of professional development is built on the foundation of knowledge, skills, and specific expertise areas of the teacher. Another principle is the engagement of participants who are considered as learners to the extent that it is possible for them to apply the skills they learn. The participants are teachers, and the best way to engage them is through the use of technology.

Tondeur et al. (2016) review the approaches that can be used to respond to challenges experienced in the professional development of teachers while integrating ICT. The authors acknowledge that teacher professional development (TPD) is an essential aspect of changes in education. Moreover, the effective use of technology is vital because it enhances learning. Although TPD might be successful in some instances, it also presents numerous challenges that should be addressed. The implementation of ICT in the education systems turns out to be challenging because of obstacles that can hinder successful integration. One of the approaches to overcome the challenges is the alignment of action at different levels, which enhances a shared vision of the most desirable aspects.

Furthermore, all stakeholders should be engaged in establishing a shared vision for the use of ICT in education. Networks of teachers should be involved in professional development to bridge the gap between practice and research. Decision-making ought to be all-inclusive to ensure that critical stakeholders are not left out. This way, it is possible to implement a successful ICT program in the professional development of teachers.

Grimmett (2014) examines how to practice the professional development of teachers based on a cultural-historical approach. In the book, the author has explored the historical development of teacher professional development and its current context. The author has used a case study approach by providing a historical account of her experiences and how they relate to the topic under discussion. From the findings, the use of the cultural-historical approach is essential in theorizing professional development. The author also illustrates that PD should be repositioned within the classroom practice of the teacher. Moreover, conscious awareness and joint activity are crucial features that could be used to enhance the professional development of teachers.

\section{DISCUSSION}

With the numerous advancements in technology, teachers have embraced the use of technological devices in the classroom. Technology is regarded as an innovative approach to teaching, and it has permeated the teaching profession. The successful integration of technology in education makes a difference because it brings numerous reforms within the classroom setting. Moreover, the professional development of teachers is closely interrelated to technology. It is essential to prepare teachers for the disruptive changes that have been brought by the adoption of modern technologies. One of the ways this can be achieved is training teachers on the importance of technology in education and how to use it in the classroom. The proliferation of teaching in the education sector means that the topic is worth studying. This paper explores the evolution of technology and how 
British Journal of Education

Vol.8, Issue 2, pp.1-12, Feburary 2020

Published by ECRTD- UK

Print ISSN: ISSN 2054-6351

Online ISSN: ISSN 2054-636X

teachers in the classroom use it. Further, the article highlights how technology supports the professional development of teachers, and ways in which it can be incorporated in training programs.

\section{Definition of Technology and how It has Evolved Over the Years}

Technology is defined as the systematic application of scientific or other organized knowledge to the practical task (Robinson et al. (2007). Educational technology, on the other hand, is defined as the study and ethical practice of facilitating learning and improving performance by creating, using, and managing appropriate technological processes and resources (Richey, 2008). Robinson et al. (2007) claim that "Educational technology is the use of both physical hardware, software, and educational theoretic to facilitate learning and improving performance by creating, using, and managing appropriate technological processes and resources" which reflect the intellectual and technical development of educational technology. It includes computer-based training, online training, and where mobile technology is used. Hence, educational technology refers to all valid and reliable applied equipment, and processes that are derived from scientific research, through integrating technology into educational settings, to promote a more diverse learning environment (Hamad et al. (2018).

The use of technological tools in the educational field has increased dramatically in the last two decades, and this has triggered changes in the educational setting (Serin, 2015). According to Serin (2015), the effective use of technological tools across educational settings provides opportunities for the development of learner's skills to achieve educational goals. According to Richey (2008) and Garrison et al. (2003), educational means have evolved through many different stages and contributed to the enhancement of the learning process, such as:

1. Visual and audiovisual educational scene (wall paintings and educational songs).

2. Communication phase (it is a dynamic process that involves the interaction of the elements of the sender that is, the teacher, devices, educational materials, and the learner)

3. The systematic approach and the development of education systems.

4. Behavioral science (This entails the behavior and response of the learner and the transition from learning materials introduced to programmed learning materials).

5. Education technology stage/phase (it emphasizes thinking on problem-solving, setting goals, and the focus of using hardware to linking it with other materials and software too).

\section{How technology is being used and Incorporated in Classrooms}

Technology use in the classroom has made work easier for teachers. The most tedious topics and tasks are adequately covered and demonstrated through technology. Through technology, teachers tap into their students' interests and, as such, encourages them to engage more in class. Many articles and researches have supported this idea. For instance, Cambridge University Press acknowledges the benefits of using technology in the classroom. Piccolo (2017) emphasizes that technology "transforms a teacher-centered class into a learner-centered one and boosts student investment and motivation" as one of the few benefits. 
British Journal of Education

Vol.8, Issue 2, pp.1-12, Feburary 2020

Published by ECRTD- UK

Print ISSN: ISSN 2054-6351

Online ISSN: ISSN 2054-636X

Teachers need to learn how to take advantage of technology. There are various ways in which technology is being incorporated and used in the classroom. One of the ways in which teachers incorporate technology is through the use of videos to conduct mini-lessons. Lesson plans can be developed and implemented better through the use of videos for specific topics. The use of videos in teaching adds a multimedia component to the lessons, and this benefits learners significantly. Animated videos have an important impact on the development of students in several areas of competence, such as creativity, memory, and critical thinking. Furthermore, multimedia elements can be added to presentations, and this enables learners to be attentive. Some of the elements include graphs, images, podcast clips, and pictographs.

Technology is also used to incorporate the input of students and collect their feedback. Numerous technological applications enable students to provide feedback during a lesson. Robinson \& Latchem (2004) assert that teachers can use polling applications to create polls and gather feedback. This enables teachers to know whether students are struggling to understand a specific topic. Students take part in the polls using smartphones. In addition, teachers use technology to collect the responses of students during a class. Moore et al. (2016) affirm that another way of using technology in the classroom is through gamification; the application of gaming mechanics makes learning fun. Teachers can use competitive models during a classroom exercise. Students can be urged to search for some facts, and the ones who get the right answers are rewarded. This approach is important because it helps in the motivation of students and enhances their learning experience.

Teachers also incorporate technology with regards to the flipped classroom model, an approach that has gained popularity in the education sector. As demonstrated by Goldberg et al. (2003), teachers tend to share information with students beforehand, and this makes it possible to use the lesson time for purposes of discussion, questions, and debate. Rather than give students conventional homework or exercises on a specific topic, they are provided with research assignments that enable them to find more about a topic. For instance, they could be asked to low for stories related to the topic of discussion. Besides, pre-recorded lectures can be given to the students to watch. Tibi et al. (2016) contend that the approach enhances learning because students already understand some key facts before attending a class. As a result, the teacher spends little time in the active transfer of knowledge and focuses on the development of students and their understanding of concepts.

Technology is also used by teachers to administer online assessments. According to West \& Graham (2005), learning management systems (LMS) have offered teachers an opportunity to design and execute assessments online. Additionally, learning management systems have become a database of information where teachers can store and distribute lessons and activities where ever they are and provide their students access to resources that are shared within the system. As such, technology not only makes it more convenient for teachers and students to use but also saves time that could be used for other essential classroom matters. 
British Journal of Education

Vol.8, Issue 2, pp.1-12, Feburary 2020

Published by ECRTD- UK

Print ISSN: ISSN 2054-6351

Online ISSN: ISSN 2054-636X

Furthermore, online exams are convenient for teachers and students. Technology is also used to run several activities simultaneously. Arcon et al. (2017) posit that teachers utilize technology to offer different activities to several students at the same time. For instance, students can be grouped into different categories and offered different tasks. The teacher can then go around the classroom to offer any needed support. Multimedia resources are essential in enabling teachers to run activities concurrently within the classroom.

\section{The use of technology in training teachers and adding to their knowledge}

Through careful design and thoughtful application, technology can accelerate learning. West \& Graham (2005) assert that technology can assist learners in unlocking learning abilities and using them in their education. For instance, teachers can use technology to understand different perspectives on an issue and put it in different contexts. While training teachers, the trainers can assist the trainees in reflecting on what they have already learned and also adjust their understanding of the issues taught. The attention of learners is easily captured through technology because it taps into their passions and interests. Technology plays an essential role in personalizing the training of teachers because it creates relevant and engaging experiences. Trainers can design different learning experiences that enable the learners to choose from a variety of options, which would include the production of media, writing of essays, collaboration with experts, and building websites.

Technology can also be used to organize learning around project-based learning and real-world challenges. As demonstrated by Robinson \& Latchem (2004), this could be achieved using diverse digital learning resources and devices that enhance competency in complex content and concepts. In comparison with writing a publication to be reviewed by the trainer, the teacher, the learner can publish his or her research online and receive feedback from fellow researchers. Further, it is possible for the teacher undergoing training to draft and share an announcement using online streaming sites, and also ask for constructive feedback from the audience. Another way of using education in the training of teachers is by taking advantage of the available opportunities in libraries, museums, and other settings outside the classroom. With the use of coordinated events, classrooms around the globe can unite through literacy. The other role of technology in teacher training is assisting learners in pursuing their interests and passions. The ability to learn about topics of self-interest enables the teachers who are learners to understand the importance of selfexploration.

Technology has the potential to support professional development among teachers. According to West \& Graham (2005), there is a need to provide teachers with collaborative opportunities during training to enhance professional learning. With the incorporation of technology, teachers can benefit from subject-specific training opportunities. Further, technology exposes teachers to models that enhance effective practice. For instance, the observation of classroom practice when technology is used to train them plays an essential role in improving their knowledge. Technology can mediate professional development by engaging teachers directly and help in overcoming the weaknesses presented by face-to-face teaching models. Thus, technology provides an opportunity 
British Journal of Education

Vol.8, Issue 2, pp.1-12, Feburary 2020

Published by ECRTD- UK

Print ISSN: ISSN 2054-6351

Online ISSN: ISSN 2054-636X

for cost-effectiveness through distance learning. Besides, technology can connect distance learners with both virtual and face-to-face trainers.

Controversy in using technology as a way to help teachers in their professional development Despite its vast potential and applicability in teacher training, the use of technology to assist teachers in their professional development has a lot of controversies. Robinson \& Latchem (2004) posit that the discussion emanates from the numerous challenges presented by the use of technology in teacher education. One of the problems is the emergence of new technological trends, which have completely changed the field of education. The rise of new trends in technology presents a significant challenge because teachers who are undergoing training might not be able to adapt to it. As a result, the applicability of the technology in education becomes challenging, and the goals of using it are not achievable. Another challenge is the failure to personalize learning; there exists a gap between the desire to deliver differentiated instruction and the technology that can facilitate this approach. Although teacher trainers want to implement personalized learning, they do not get access to the tools needed to attain it.

The other challenge is the inability to use technology while delivering formative assessments. According to Inoue (2007), it is evident that assessments are significant drivers and determinants of educational changes. In the recent past, formative assessments have become common in instructional practice. However, there exists a gap because educational institutions are unable to implement new skill demands. It has become challenging for teacher trainers to use simple digital tools that would be helpful in the assessment and training of teachers. Another challenge is that lesson planning could be labor-intensive with the use of technology. The adaptation of technology for teacher professional development can be overwhelming for trainers. For instance, the function of lesson planning might not be available in the software used for teacher professional development. As a result, the use of technology can have a significant effect on the flow of lessons and contribute to regular disruptions.

It is also challenging to use technology in teacher professional development when there are inadequate infrastructure and ICT support. As highlighted by McDermott (2019), the success of technology in teacher development is determined by the availability of infrastructure and ease of access to technical support. When these resources are inadequate, it becomes challenging for instructors to train teachers. Further, the inadequacy of the needed infrastructure implies that the professional development of teachers will become compromised. Controversy also emanates from the fact that some teachers do not believe in technology. Some teachers believe that face-to-face instruction is the most effective approach to teaching. This means that it is challenging to train such teachers as they would not align with the learning goals or portray any commitment to embrace technology as an instructional strategy.

The use of technology to help teachers in their professional development also becomes controversial because of resistance. The majority of teachers report that they are impressed with their current instructional methods. Teachers who feel that current lesson plans meet the students' 
British Journal of Education

Vol.8, Issue 2, pp.1-12, Feburary 2020

Published by ECRTD- UK

Print ISSN: ISSN 2054-6351

Online ISSN: ISSN 2054-636X

needs are not motivated to change them. Inoue (2007) observes that there is a lot of time spent in the preparation of good lesson plans that enhance learning and make it exciting. Revising the plans implies that the teacher would have to do some additional work, and this might have an impact on their schedule. Moreover, the adoption of classroom technologies creates the problem of double innovation, which means additional preparation. The teacher has to learn the technology before deciding to integrate it into the curriculum and classroom objectives. This makes teachers avoid technology or embrace it in their professional development.

\section{CONCLUSION}

Technology plays an essential role in the training of teachers. Technology is not only helpful to students but also their teachers who need it for professional development. The relevant knowledge, expertise, and skills in technology help teachers to pass the same to students in the classroom. In the age of information technology, almost every profession is dependent on computer literacy. The education career is not left out as it is one of the professions that has embraced the use of technology. Teachers need the necessary training to gain technological skills, which will help in facilitating their teaching experience. Training and development programs for teachers should integrate education as one of the core components.

Additionally, institutions should take advantage of technology to help teachers in their professional development. It is worth noting that the incorporation of technology in teacher education programs cannot be underscored. Thus, teachers should have adequate knowledge of the current trends in technology and how they can be used in the field of education.

\section{Recommendations}

There is abundant room for further progress in determining the uses of technology in ESL instruction and learning. The study's present literature showed that as technology continues to evolve, so does the need to stay constantly informed and updated with it. Thus, this study recommends that teachers should actively take part in being constantly aware of the developments and changes in technology. Furthermore, teachers should also realize how they can maximize their knowledge of technology and use it to tap into the interests of the learners. Additionally, because technology is proven to be an important tool in helping teachers work productively and efficiently, schools and universities must continuously find ways to support the use of technology in classrooms.

\section{REFERENCES}

Arcon, N., Klein, P. D., \& Dombroski, J. D. (2017). Effects of dictation, speech to text, and handwriting on the written composition of elementary school English language learners. Reading \& Writing Quarterly, 33(6), 533-548.

Betrus, A. K. \& Molenda, M. (2002). Historical evolution of instructional technology in teacher education programs. TechTrends, 46 (5), 18-21. 
British Journal of Education

Vol.8, Issue 2, pp.1-12, Feburary 2020

Published by ECRTD- UK

Print ISSN: ISSN 2054-6351

Online ISSN: ISSN 2054-636X

Casteel, C. J. \& Ballantyne, K. G. (2010). Professional development in action: Improving teaching for English learners. Washington, D.C: National Clearinghouse for English Language Acquisition. Retrieved from: https://files.eric.ed.gov/fulltext/ED512636.pdf

Chong, C. S. (2018). Ten trends and innovations in English language teaching for 2018. Retrieved from:

https://www.britishcouncil.org/voices-magazine/ten-trends-innovations-english-languageteaching-2018

Darling-Hammond, L., Hyler, M. E., Gardner, M., \& Espinoza, D. (2017). Effective teacher professional development. Retrieved from:

https://learningpolicyinstitute.org/sites/default/files/productfiles/Effective_Teacher_Professional _Development_REPORT.pdf

Galaczi, E., Nye, A., Poulter, M., \& Allen, H. (2018). Teacher professional development. Retrieved from:

https://www.cambridgeenglish.org/Images/539683-perspectives-teacher-professionaldevelopment.pdf

Garrison, D. R. \& Anderson, T. (2003). Definitions and Terminology Committee. E-Learning in the $21^{\text {st }}$ Century: A Framework for Research and Practice. London: Routledge.

Goldberg, A., Russell, M. \& Cook, A. (2003). The effect of computers on student writing: A metaanalysis of studies from 1992 to 2002. The Journal of Technology, Learning and Assessment, 2, 1-52.

Grimmett, H. (2014). The practice of teachers' professional development: A cultural-historical approach. Rotterdam: Brill | sense.

Hamad, A., Alkhalaileh, M. \& Rababah, O. (2018). Educational Technology Development, History, Future, and its Benefit in the Educational Process. Science Studies: An Interdisciplinary Journal for Science and Technology Studies, 12 (12), 11-19.

Inoue, Y. (2007). Technology and diversity in higher education: New challenges. Hershey, PA: Information Science Pub., an imprint of Idea Group.

Linda, B. L. (2018). 7 ways to maximize professional learning: Take advantage of technology to help teachers advance. District Administration, 54(9).

Liu, S. H., Tsai, H. C., \& Huang, Y. T. (2015). Collaborative professional development of mentor teachers and pre-service teachers in relation to technology integration. Educational Technology \& Society, 18(3), 161-172.

McDermott, P. E. (2019). Teacher training: Perspectives, implementation, and challenges. New York: Nova Science Publishers.

Moore, K. A., Rutherford, C., \& Crawford, K. A. (2016). Supporting postsecondary English language learners' writing proficiency using technological tools. Journalof International Students, 6(4), 857-872.

Piccolo, L. (2017, May 16). How can teachers encourage learning by using technology in the classroom? Retrieved January 19, 2020, from Cambridge University Press: https://www.cambridge.org/elt/blog/2017/05/16/can-teachers-encourage-learning-usingtechnology-classroom/ 
British Journal of Education

Vol.8, Issue 2, pp.1-12, Feburary 2020

Published by ECRTD- UK

Print ISSN: ISSN 2054-6351

Online ISSN: ISSN 2054-636X

Philips, P. (2008). Professional development as a critical component of continuing teaching quality. Australian Journal of Teacher Education, 33(1), 1-11.

Richey, R.C. (2008). Reflections on the 2008 AECT Definitions of the field. TechTrends, 52 (2), 24-25. DOI: 10.1007/s11527-008-0108-2.

Robinson, R., Molenda, M. \& Rezabek, L. (2007). "Facilitating Learning” (PDF). Association for Educational Communication and Technology. Retrieved 18 March 2016.

Richards, J. C. \& Farrell, T. S.C. (2005). Professional development for language teachers. Retrieved from:

https://assets.cambridge.org/97805218/49111/sample/9780521849111ws.pdf

Robinson, B. \& Latchem, C. (2004). Teacher education through open and distance learning: World review of distance education and open learning, Volume 3. London: Routledge.

Serin, H. (2005). The Role of Technology in Whole-Class Teaching. Ishik University, Erbil, Iraq.

Tibi, S., Stall, P., Joshi, M., \& Park, Y. (2016). Language knowledge and self-efficacy of preservice teachers in the United Arab Emirates: An exploratory study. Arab Journal of Applied Linguistics, 1(1), 74-96.

Tondeur, J., Forkosh-Baruch, A., Prestridge, S., Albion, P., \& Edirisinghe, S. (2016). Responding to challenges in teacher professional development for ICT integration in education. Educational Technology \& Society, 19 (3), 110-120.

West, R. E. \& Graham, C. R. (2005). Five powerful ways technology can enhance teaching and learning in higher education. Educational Technology, 45(3), 20-27. 